\title{
Jermut, korpisoturit ja militaristit suomalaisessa sotakirjallisuudessa
}

\section{Arto Jokinen, Isänmaan miehet: Maskuliinisuus, kansakunta ja väkivalta suomalaisessa sotakirjallisuudessa. Toim. Markku Soikkeli ja Ville Kivimäki. Tampere: Vastapaino 2019, 296 S.}

Arto Jokinen (1964-2016) oli suomalaisen miestutkimuksen uranuurtaja, ja Markku Soikkelin ja Ville Kivimäen toimittama ja tietokirjaksi muokkaama, postuumina ilmestynyt Isänmaan miehet: Maskuliinisuus, kansakunta ja väkivalta suomalaisessa sotakirjallisuudessa, saattaa loppuun hänen kesken jääneen väitöskirjaprojektinsa. Kirja on kokonaisuudessaan arvokas lisä Jokisen jo elinaikanaan voimakkaasti muokkaamaan suomalaisen miestutkimuksen kenttään, ja löytänee yleisöä akateemisten sota- ja miestutkimuksesta kiinnostuneiden tutkijoiden lisäksi myös muun lukevan yleisön joukosta.

Kirjallisuuden- ja kulttuurintutkijana ansioitunut Markku Soikkeli ja eritoten sotahistorian tuntijana maineikas Ville Kivimäki muodostavat yhteisellä osaamisellaan pätevän toimittajaparin Jokisen sotakirjallisuuden historiasta ammentavalle tutkimukselle. Kivimäki avaa esipuheessaan (8-16) toimitustyön haasteita: Kirja on koottu muokkaamalla Jokisen tietokoneelta löytynyttä puolivalmista käsikirjoitusversiota, ja monia keskeneräisiksi jääneitä tulkintoja ja johtopäätöksiä on jouduttu poistamaan. Koska Soikkeli ja Kivimäki eivät luonnollisestikaan ole halunneet tehdä uusia tulkintoja Jokisen puolesta, on toimitustyössä jouduttu tekemään kompromisseja ja vaikeita ratkaisuja. Kirjan lukijalle toimitustyön haasteet, muutamaa toistoa sisältävää tai lyhyehköksi jäänyttä analyysia lukuun ottamatta, eivät onneksi kuitenkaan pääsääntöisesti välity, vaan Soikkeli ja Kivimäki ovat onnistuneet luomaan keskeneräisestä työstä hyvin omilla jaloillaan seisovan itsenäisen teoksen, joka kunnioittaa Jokisen elämäntyön tärkeyttä.

Isänmaan miehet on jaettu neljään päälukuun, joista ensimmäisessä Jokinen käsittelee Suomen sotaa (1808-1809) ja erityisesti Runebergin Vänrikki Stoolin tarinoiden pitkäkestoista vaikutusta suomalaiseen soturimytologiaan. Toisessa pääluvussa tarkastelun kohteena on vuoden 1918 sisällissota ja sen kirjallisuus. Kolmas ja neljäs pääluku keskittyvät toiseen maailmansotaan; talvisotaan (1939-1940) ja sen myyttisen "hengen" esittämiseen kirjallisuudessa sekä vuosien 1941-1944 jatkosotaan, jota käsitellessään Jokinen analysoi muun muassa 
Väinö Linnan Tuntemattoman sotilaan Rokka-hahmon maskuliinisuutta Rokan silmittömän tappamisvimman kautta.

Jokisen kirjan tulevaa sotakirjallisuus- ja miestutkimusta eniten hyödyttävät havainnot liittyvät erityisesti kahteen seikkaan. Ensinnäkin hänen analyysinsä representaatioiden voimasta kansallisen, usein väkivaltaisen ja nationalistisen hegemonisen maskuliinisuuden luomisessa on vakuuttava. Toiseksi, hänen kirjallisen aineistonsa pohjalta määrittelemät "kolme miessubjektiutta" eli "jermu", "korpisoturi" ja "militaristinen soturisubjekti" (280-281) mahdollistavat kriittisen tutkimuksen näiden subjektiuksien vaikutuksesta sekä Suomen (sota)historialliseen kehitykseen että nykyisin vallalla oleviin miehen malleihin.

Representaatioita käsitellessään Jokinen tulkitsee, että sotakirjallisuus ja muut sotaa käsittelevät mediat ovat"sukupuolen teknologioita" (194), jotka eivät ole muusta yhteiskunnasta irrallisia puhtaasti fiktiivisiä narratiiveja, vaan suomalaiseen yhteiskuntaan ja sukupuolittuneeseen väkivaltaan kiinteästi liittyviä ja hegemonista maskuliinisuutta tuottavia ja uusintavia välineitä. Jokinen on erityisen kriittinen sitä kohtaan, kuinka toistuvat representaatiot miehistä ei vain "oikeutetuissa" vaan suorastaan glorifioiduissa tappamiskuvauksissa luonnollistavat maskuliinisuuden ja väkivallan suhdetta, ja kuinka tämän suhteen luonnollisuutta pidetään tarpeellisena itsenäisen kansallisvaltion ylläpitämisessä. Implisiittisesti miehen ja väkivallan suhde kansakunnan puolustuksessa myös ylläpitää miehen "luonnollista" oikeutta hallita naisia, vaikkakin Jokinen myös tuo ansiokkaasti esiin sen, kuinka sukupuoliroolit varsinkin jatkosodan aikana ja jälkeen muuttuivat ainakin joiltain osin tasa-arvoisemmiksi.

Jokisen määrittelemät kolme miessubjektia luovat myös hedelmällisen pohjan tulevalle tutkimukselle. Tässä yhteydessä erityisen kiinnostavaksi nousee näiden miessubjektien suhde luontoon. Jokinen määrittelee sekä jermun mutta varsinkin korpisoturin näiden luontosuhteen kautta. Hän tuo esiin, kuinka suomalaisten mytologisoitu erityissuhde luontoon, luonnon hyödyntäminen, erätaidot ja äärimmäinen fyysinen kestävyys luovat soturisubjektin, joka on paitsi työväenluokkainen, myös luontosuhteeltaan oppositiossa militaristista, usein upseeristoon kuuluvaa luonnosta vieraantunutta ja teknologiaan luottavaa subjektia kohtaan. Tämä subjekti ei "ole yhtä luonnon vaan luonnottoman sotakoneensa kanssa” (281).

Kokonaisuudessaan Isänmaan miehet onnistuu luomaan kattavan katsauksen suomalaisesta sotakirjallisuudesta löytyviin maskuliinisuuksiin ja näiden maskuliinisuuksien edelleen jatkuvaan vaikutukseen nykypäivänä. On sääli, ettei Jokinen itse päässyt saattamaan työtään loppuun, koska varsinkin yllä mainituista kolmesta soturisubjektista olisi mielellään lukenut enemmänkin. Soikkelin ja Kivimäen toimitustyön ansiosta tutkijoiden on nyt kuitenkin mahdollista perehtyä aiheeseen. Isänmaan miehien postuumi julkaisu on siksi tärkeä tapahtuma suomalaisessa miestutkimuksessa.

Harri Salovaara 